\title{
Treatment Adherence as a New Choice Factor for Optimization of Oral Anticoagulation Therapy in Patients with Atrial Fibrillation and Hemostatic Gene Polymorphisms
}

\author{
Yulia P. Skirdenko1, Alexander V. Shustov², Valeriy V. Zherebilov¹, Nikolay A. Nikolayev1* \\ 1 Omsk State Medical University. Lenina ul. 12, Omsk, 644099 Russia \\ 2 Omsk Regional Clinical Cardiology Dispensary. Lermontova ul. 41, Omsk, 644024 Russia
}

\begin{abstract}
Aim. To evaluate treatment adherence and prevalence of CYP2C9 and VKORC1 gene mutations in patients with atrial fibrillation (AF) and provide rationale of choice for oral anticoagulation therapy.

Material and methods. Treatment adherence was evaluated in 137 AF patients (aged 35-85 years) with quantitative estimation of drug therapy adherence along with compliance to medical support and lifestyle modifications. Among them 82 patients underwent polymerase chain reaction (PCR) analysis of CYP2C9 and VKORC1 gene polymorphisms.

Results. Patients receiving anticoagulation therapy are characterized by lower level of adherence compared to patients without anticoagulants (65.2 $\pm 19.3 \%$ vs $68.5 \pm 19.1 \%$; Wald-Wolfowitz; $p<0.05)$. Considering all studied parameters men are less adherent than women $(54.7 \pm 18.6 \%$ vs $60.6 \pm 16.7 \%$; Kolmogorov-Smirnov; $\mathrm{p}<0.05$ ). Patients receiving new oral anticoagulants (NOAC) have better compliance compared with patients of warfarin group. Mutations in CYP2C9 gene were detected in $32.9 \%$, VKORC1 - in $68.3 \%$, and their combination - in $21.9 \%$ of study participants. Warfarin therapy may be potentially dangerous in such patients due to low adherence.

Conclusion. Considering high prevalence of CYP2C9 and VKORC1 gene mutations treatment adherence should be estimated to optimize choice of anticoagulation therapy. NOAC treatment should be considered in patients with low adherence for prevention of thromboembolic complications.
\end{abstract}

Keywords: warfarin, new oral anticoagulants, adherence, CYP2C9, VKORC1.

For citation: Skirdenko Y.P., Shustov A.V., Zherebilov V.V., Nikolayev N.A. Treatment Adherence as a New Choice Factor for Optimization of Oral Anticoagulation Therapy in Patients with Atrial Fibrillation and Hemostatic Gene Polymorphisms. Rational Pharmacotherapy in Cardiology 2016;12(5):494-502. (In Russ). DOI: 10.20996/1819-6446-2016-12-5-494-502

\footnotetext{
Приверженность к лечению как новый фактор выбора пероральных антикоагулянтов у носителей мутаций системы гемостаза больных фибрилляцией предсердий

Юлия Петровна Скирденко 1, Александр Валентинович Шустов², Валерий Валерьевич Жеребилов 1 , Николай Анатольевич Николаев ${ }^{*}$ 1 Омский государственный медицинский университет. Россия, 644099, Омск, ул. Ленина, 12

2Клинический кардиологический диспансер. Россия, 644024, Омск, ул. Лермонтова, 41
}

\begin{abstract}
Цель. Оценить приверженность к лечению и распространенность мутаций генов CYP2C9 и VKORC1 у пациентов с фибрилляцией предсердий (ФП), а также обосновать принципы выбора пероральных антикоагулянтов для этой категории пациентов.

Материал и методы. У 137 больных ФП 35-85 лет изучили приверженность к лечению с количественным расчетом показателей приверженности к лекарственной терапии, медицинскому сопровождению и модификации образа жизни. У 82 больных из этой же выборки методом полимеразной цепной реакции исследовали полиморфизм генов CYP2C9 и VKORC1.

Результаты. Для пациентов, получающих антикоагулянтную терапию, характерен более низкий уровень приверженности к лечению в сравне-

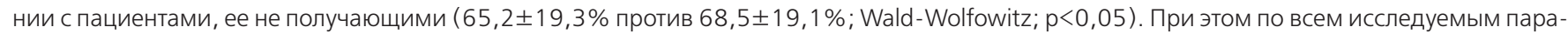

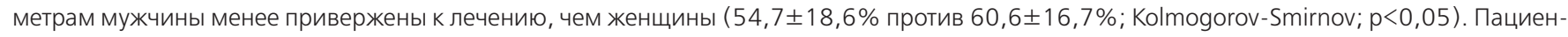
ты, получающие варфарин, менее привержены к лекарственной терапии в сравнении с пациентами, получающими новые пероральные антикоагулянты (HOAK). Мутации гена СYР2C9 выявлены у 32,9\%, VKORC1 - у 68,3\%, а их одновременное носительство - у 21,9\% участников исследования. У таких больных низкий уровень приверженности к лечению делает терапию варфарином потенциально опасной.

Заключение. В условиях высокой распространенности мутаций генов CYP2C9 и VKORC1 для обоснования выбора антикоагулянтной терапии, наряду с прочим, целесообразно количественно оценивать приверженность к лечению. У пациентов с выявленной низкой приверженностью к лечению для профилактики тромбоэмболических осложнений антикоагулянтную терапию следует начинать с НОАК.
\end{abstract}

Ключевые слова: варфарин, новые пероральные антикоагулянты, приверженность, СYP2C9, VKORC1.

Для цитирования: Скирденко Ю.П., Шустов А.В., Жеребилов В.В., Николаев Н.А. Приверженность к лечению как новый фактор выбора пероральных антикоагулянтов у носителей мутаций системы гемостаза больных фибрилляцией предсердий. Рациональная фармакотерапия в кардиологии 2016;12(5):494-502. DOI:10.20996/1819-6446-2016-12-5-494-502

*Corresponding author (Автор ответственный за переписку): niknik.67@mail.ru

Received / Поступила: 15.06.2016

Accepted / Принята в печать: 14.07.2016 
Atrial fibrillation $(\mathrm{AF})$, occurring with a frequency of $0.4 \%$ to $2 \%$, represents one of the most common cardiac arrhythmias and is independently associated with a 5 -fold increased risk of ischemic stroke [1]. High-risk patients with non-valvular AF are traditionally prescribed vitamin $\mathrm{K}$ antagonists (warfarin, phenindione et al.) or direct thrombin/Xa factor inhibitors also called new oral anticoagulants (NOAC) for stroke prevention.

Warfarin has been used for decades, however, considering some pharmacokinetic and pharmacodynamic features, potential drug and food interactions along with narrow therapeutic range, it requires thorough monitoring of international normalized ratio (INR) level, while treatment is potentially accompanied by complications. Optimal INR range of 2.0 to 3.0 units is associated with reduced risk of stroke by $64 \%$, but large meta-analysis of eight randomized studies shows that patients on warfarin present target therapeutic range of INR only during 55-68\% of the time [2].

Inadequate INR control in patients receiving warfarin may contribute to serious adverse events in 12\% of cases while $2 \%$ of complications lead to death [3]. It was demonstrated that $3.8 \%$ of patients taking warfarin experienced minor gastrointestinal bleeding, 1.9\% - major bleeding, and $0.4 \%$ - intracranial hemorrhage [2]. Hemorrhagic complications are often associated with numerous predisposing factors, including food and drug interactions, dosage regimen violation as well as gene mutations involved in warfarin metabolism. However, reliable strategies to prevent bleeding complications are still lacking.

Warfarin should be taken at one and the same time, and its potential pharmacological interactions require strict consideration of all concomitant therapy. Patients need to be aware of the importance of regular lab visits and longtime INR control despite significant time consumption. Thus, high adherence to medical treatment is necessary to provide adequate prophylaxis of warfarin therapy complications.

In respect of possible food interaction of warfarin, dietary interventions also contribute the prevention of excessive or insufficient anticoagulation. Eating foods containing vitamin $\mathrm{K}$ is not prohibited but requires regular and unvaried dietary regimen. At the same time a whole series of food interactions between warfarin and garlic, green tea, grapefruit, grapes, cranberries etc. are reported and therefore their concomitant use is not recommended. High adherence to diet requirements can be achieved only in patients with good compliance to lifestyle modifications.

Unpredictable variability of warfarin concentration represents another challenging problem in patients with mutations of CYP2C9 and VKORC1 genes,
Фибрилляция предсердий (ФП), встречаясь с частотой от 0,4\% до $2 \%$, является одной из самых распространенных форм нарушения сердечного ритма. Ее наличие независимо связано с 5-кратным увеличением риска ишемического инсульта [1]. Для профилактики инсульта в группах повышенного риска у пациентов с неклапанным генезом ФП общепринято назначение антагонистов витамина К (варфарин, фениндион и др.) или новых пероральных антикоагулянтов (НОАК) - прямых ингибиторов тромбина, прямых ингибиторов Ха фактора свертывания.

Варфарин используется на протяжении многих десятилетий, однако вследствие особенностей фармакокинетики и фармакодинамики, большого числа лекарственных и пищевых взаимодействий и узкого терапевтического диапазона, его прием требует тщательного мониторинга уровня международного нормализованного отношения (МНO) и часто сопровождается осложнениями. В дозе, поддерживающей МHO от 2,0 до 3,0 ед., варфарин снижает риск инсульта на $64 \%$, однако метаанализ восьми рандомизированных исследований свидетельствует, что в целевом терапевтическом диапазоне МНО остается только в 55-68\% времени [2]. Недостаточный контроль МНО на фоне приема варфарина у $12 \%$ пациентов сопровождается серьезными нежелательными эффектами, которые у $2 \%$ пациентов приводят к смерти [3]. На фоне приема варфарина 3,8\% пациентов перенесли малые желудочно-кишечные кровотечения, 1,9\% - большие кровотечения, а 0,4\% - внутричерепное кровоизлияние [2]. Развитие геморрагических осложнений часто связано с воздействием многочисленных случайных факторов, включая пищевые и лекарственные взаимодействия, нарушение режима приема и дозирования, а также наличием мутаций генов, участвующих в метаболизме варфарина. Однако надежные способы предотвращения геморрагических осложнений пока отсутствуют.

Варфарин следует принимать в одно и то же время, а его многочисленные лекарственные взаимодействия требуют строгого учета и соблюдения дозировок всех совместно принимаемых лекарств. Длительный и регулярный контроль МНО требует от пациента осознания важности и готовности к систематическому посещению лаборатории и врача, затрат личного времени. Таким образом, высокая приверженность к медицинскому сопровождению является необходимым условием для обеспечения профилактики осложнений терапии варфарином.

Учитывая пищевые взаимодействия варфарина, соблюдение диеты также относится к способам профилактики чрезмерной или недостаточной антикоагуляции. Употребление продуктов, содержащих витамин К, не запрещено, но требуется регулярное и одинаковое их потребление. При этом описан целый ряд пищевых взаимодействий варфарина с чесноком, зеленым чаем, грейпфрутом, виноградом, клюквой и др., употребление которых при его приеме нежелательно. Жесткое соблюдение требований диеты осу- 
providing up to $50 \%$ of dose variation in European population.

The most significant mutations and common polymorphic alleles are CYP2C9*2 and CYP2C9*3. Both alleles contribute to significant decrease in CYP2C9 enzyme activity whereas carriers of those allelic variants represent more than 3-fold increase of bleeding risk due to excessive anticoagulation [4]. The presence of CYP2C9*2 or CYP2C9*3 alleles is associated with $12 \%$ and $5 \%$ residual fermentative activity, respectively [5]. It consequently reduces the rate of biotransformation of xenobiotics while increasing their peak concentration. As a result, carriers of these mutations are "slow metabolizers", while overall prevalence of CYP2C9 variant is $20-25 \%$ in hepatic cytochrome P450 enzymes and CYP2C9 activity is reduced mostly in case of CYP2C9*3 polymorphism [5]. This is especially important as AF patients may be administered various drugs metabolized by cytochrome P450 (amiodarone, losartan, torasemide, ibuprofen, celecoxib, omeprazole, norfloxacin, erythromycin and others). In general, concomitant medicaments and foods can provide up to $20 \%$ of the variability of warfarin dose [4].

As a product of another important VKORC1 gene, subunit 1 of phyllochinone-epoxide reductase complex may also contribute to warfarin activity. Approximately $45 \%$ of Europeans have T-allele in the locus 1173 of VKORC1 gene, which is accompanied by high sensitivity to warfarin and the risk of over-anticoagulation [5]. Genetic polymorphism of C+1173T and $\mathrm{G}+3673 \mathrm{~A}$ alleles is associated with increased activity of the VKORC1 enzyme; therefore reduction of background warfarin dose is needed.

Mutations in VKORC1 and CYP2C9 genes can determine about half of dose dispersion in patients taking warfarin and thereby predispose to various complications. Although VKORC1 or CYP2C9 gene polymorphisms or its combination not always lead to bleeding events, such patients may need lower dose of warfarin and require aggressive control of coagulation state while the risk of drug interactions is higher. We believe that combined effect of several factors is very dangerous. Violation of warfarin treatment regimen is accompanied by high risk of bleeding complications, while its combination with VKORC1 and CYP2C9 gene mutations can lead to very serious consequences.

Nowadays the prevalence of VKORC1 and CYP2C9 polymorphisms in Russia is underinvestigated. Data about Western Siberia population, which is characterized by specific ethnic and historical features with high prevalence of Mongoloid genes, are lacking. Quantitative assessment of treatment adherence in ществимо лишь пациентами с высокой приверженностью к модификации образа жизни.

Еще одну проблему представляет непредсказуемость концентрации варфарина при мутациях генов CYP2C9 и VKORC1, обеспечивающих до 50\% вариабельности его дозы у лиц европейского происхождения.

Наиболее значимыми и часто встречающимися полиморфными аллелями являются СYP2C9*2 и CYP2C9*3. Оба аллеля связаны с заметным снижением активности фермента СYP2С9, и у носителей таких аллельных вариантов риск кровотечений из-за чрезмерной антикоагуляции возрастает более чем в 3 раза [4]. Наличие аллеля CYP2C9*2 приводит к $12 \%$ остаточной ферментативной активности, а аллеля CYP2C9*3 - к 5\% [5]. Это, соответственно, снижает скорость биотрансформации ряда ксенобиотиков и повышает их пиковую концентрацию. В результате носители указанных мутаций являются «медленными метаболизаторами», при этом активность СYР2С9 снижается в большей степени при наличии варианта CYP2C9*3, а фермент CYP2C9 Составляет 20-25\% от печеночной системы цитохрома P450 [5]. Последнее тем более важно, поскольку пациентам с ФП по основному и сопутствующим заболеваниям может быть назначен ряд препаратов, метаболизирующихся с его участием (амиодарон, лозартан, торасемид, ибупрофен, целекоксиб, омепразол, норфлоксацин, эритромицин и другие). В целом принимаемые лекарственные средства и пищевые продукты могут обеспечить до 20\% изменчивости дозы варфарина [4].

Не менее важным по влиянию на активность варфарина является ген VKORC1, продукт которого - субъединица 1 филлохинон-эпоксидредуктазного комплекса - служит ферментом активации варфарина. Приблизительно 45\% европейцев имеют Т-аллель в локусе 1173 гена VKORC1, что сопровождается высокой чувствительностью к варфарину и риском чрезмерной антикоагуляции [5]. Носительство полиморфных аллелей C+1173Т и G+3673A гена VKORC1 сопровождается повышением активности фермента VKORC1 и необходимостью снижения фоновой дозы варфарина.

Мутации VKORC1 и СYP2C9 объясняют около половины дисперсии доз у пациентов, принимающих варфарин, что создает широкий круг предпосылок к развитию осложнений. И хотя сам факт наличия мутаций и/или их сочетания не обязательно приводит к геморрагическим осложнениям, пациентам с мутациями генов VKORC1 и СYP2C9 может требоваться меньшая доза варфарина, риск лекарственных взаимодействий у них выше, а контроль статуса коагуляции должен быть еще более жестким. Совместное же воздействие нескольких факторов, на наш взгляд, является весьма опасным. Нарушение технологии терапии варфарином само по себе несет высокие риски геморрагических осложнений, а в сочетании с наличием мутаций генов VKORC1 и CYP2C9 может привести к крайне тяжелым последствиям. 
AF patients receiving anticoagulants was first available in 2015 and was never performed before in Siberia region.

Aim of the study was to evaluate treatment adherence and prevalence of CYP2C9 and VKORC1 gene mutations in patients with $\mathrm{AF}$ and provide rationale of choice for oral anticoagulation therapy.

\section{Material and methods}

The study included $137 \mathrm{AF}$ patients (68 men and 69 women) aged 35 to 85 years who were hospitalized to Omsk Regional Clinical Cardiology Dispensary and Omsk Municipal Clinical Hospital\#2. Index of clinical symptoms evaluation of European Heart Rate Association (EHRA) distributed by classes of severity as follows: EHRA-I - in 4 patients ( 3 men, 1 woman), EHRA-II - in 63 patients (32 men, 31 women), EHRA-III - in 64 patients ( 31 males, 33 females), and EHRA-IV - in 6 patients ( 2 men, 4 women). The study was performed in accordance with medical standard 91500.11.0002-2002.

The first stage included quantitative assessment of drug treatment adherence and compliance to medical support and life style modification [8] using a questionnaire consisting of 25 multiple choice questions. Then the score was summarized and treatment compliance was calculated.

At the second stage, 82 patients ( 39 men and 43 women) aged 35-85 years, were randomized into subgroup to evaluate the polymorphism of CYP2C9 and VKORC1 genes with polymerase chain reaction (PCR) analysis. Alleles of rs1799853 (Arg144Cys, CYP2C9*2) and rs1057910 (lie359Leu, CYP2C9*3) of CYP2C9 gene along with rs9934438 (C+1173T) and rs9923231 ( $\mathrm{G}+3673 \mathrm{~A})$ of VKORC1 gene were identified. The study was performed in central research laboratory of Omsk State Medical University.

The level of statistical significance was determined at $\alpha$ probability less than 0.05 . In all possible cases of parametric study t-test Student was used. The most sensitive criteria for non-parametric analysis were Wald-Wolfowitz, Mann-Withney, KolmogorovSmirnov, Kruskal-Wallis, Pierson and the median test. Other non-parametric criteria were used for matched or paired data including Friedman, Kendall $(\tau)$ and Spearman's rank correlation $\left(\rho_{s}\right)$ coefficients along with Wilcoxon Signed Rank Test. Pearson's $\chi^{2}$ test and Fisher criterion were applied for unpaired data to evaluate the independence of the nominal variables. Both the McNemar's and Cochran's Q tests provided stronger evidence for a statistically significant treatment effect of different tactics. Statistical analysis was performed using Statistica 6.1 software (Statsoft Inc., USA).
При этом распространенность полиморфизма генов VKORC1 и CYP2C9 в России изучена мало, а в популяции Западной Сибири, имеющей свои этнические и исторические особенности формирования и высокое количество «Монголоидных» генов, такие исследования до настоящего времени отсутствовали. В связи с тем, что методы количественной оценки приверженности до 2015 г. отсутствовали, у получающих антикоагулянты больных ФП количественная оценка приверженности к лечению ранее не выполнялась.

Целью исследования было оценить приверженность к лечению и распространенность мутаций генов СYP2C9 и VKORC1 у больных ФП, а также обосновать принципы выбора пероральных антикоагулянтов для этой категории пациентов.

\section{Материал и методы}

В исследование включено 137 пациентов с ФП (68 мужчин и 69 женщин) в возрасте от 35 до 85 лет, находящихся на стационарном обследовании и лечении в БУЗОО «Клинический кардиологический диспансер» (Омск) и БУЗОО ГКБСМП № 2 (ОМСК).

Индекс оценки клинических симптомов Европейской ассоциации сердечного ритма (EHRA), связанных с ФП, распределялся по классам тяжести следующим образом: EHRA-I - у 4 пациентов ( 3 мужчины, 1 женщина), EHRA-II - у 63 (32 мужчины, 31 женщина), EHRA-III - у 64 (31 мужчины, 33 женщин) и EHRA-IV у 6 (2 мужчины, 4 женщины). Исследование выполнено в соответствии с ОСТ 91500.11.0002-2002.

Первый этап исследования включал количественную оценку приверженности к лекарственной терапии, приверженности медицинскому сопровождению и приверженности модификации образа жизни по Н.А. Николаеву (2015) [8] с использованием опросника, включающего 25 вопросов с 6 -ю вариантами ответов. Ответ на каждый вопрос оценивали в баллах, которые суммировали и рассчитывали показатели приверженности.

На втором этапе в сформированной методом рандомизации подвыборке из 82 пациентов (39 мужчин и 43 женщины) в возрасте 35-85 лет оценили полиморфизм генов CYP2C9 и VKORC1 методом полимеразной цепной реакции (ПЦР). Определяли носительство полиморфных аллелей rs1799853 (Arg144Cys, CYP2C9*2) и rs 1057910 (lie359Leu, CYP2C9*3) гена CYP2C9; rs9934438 (C+1173T), и rs9923231 (G+3673A) гена VKORC1. Исследование материала выполняли на базе ЦНИЛ ГБОУ ВПО «ОмГМУ» Минздрава РФ.

При статистической обработке данных уровнем значимости устанавливали вероятность $\alpha$ менее 0,05. Во всех случаях при возможности параметрического исследования применяли t-критерий Student. Если поставленные задачи не могли быть им решены, применяли непараметрический анализ, в каждом конкретном случае отдавая предпочтение наиболее чувствительному критерию. Для проверки гипотез о принадлежности независимых выборок к однородным сово- 


\section{Results}

The study enrolled $137 \mathrm{AF}$ patients, among them 68 men (mean age $65 \pm 10.3$ years; body mass index $31.3 \pm 6.1 \mathrm{~kg} / \mathrm{m}^{2}$ ) and 69 women (mean age $67.8 \pm 8.3$ years; body mass index $\left.29.3 \pm 4.7 \mathrm{~kg} / \mathrm{m}^{2}\right)$. Age structure of participants is represented on figure 1 .

Newly diagnosed AF was registered in 4 patients $(2.9 \%), 44$ patients had paroxysmal form (32.1\%), 47 patients demonstrated persistent form (34.3\%) and permanent AF was diagnosed in 42 cases $(30.7 \%)$. The majority of patients $(n=89,65 \%)$ received anticoagulants with overall rate of warfarin and NOAC administration of $45.3 \%$ (62 cases) and $19.7 \%$ ( 27 cases), respectively, while 48 patients received antiplatelet therapy (35\%).

Patients treated with anticoagulants, demonstrated lower level of adherence to the treatment compared with patients not receiving anticoagulants. The most significant differences were observed in the level of adherence to drug therapy (65.2 $\pm 19.3 \%$ vs $68.5 \pm 19.1 \%$, respectively; Wald-Wolfowitz; $p<0.05$ ). Men were significantly less compliant than women: adherence to drug therapy was $54.7 \pm 18.6 \%$ vs $60.6 \pm 16.7 \%$, respectively (Kolmogorov-Smirnov; $p<0.05)$ while compliance to medical support was $60.1 \pm 19.6 \%$ vs $70.2 \pm 17.8 \%$, respectively (WaldWolfowitz; $p<0.05$ ).

Finally, overall (regardless of sex) treatment adherence was lower in patients taking warfarin compared with those receiving NOAC $(63.8 \pm 19.2 \%$ vs $68.3 \pm 19.7 \%$, respectively), although the difference wasn't statistically significant. Among men, receiving NOAC, compliance with the medical support was significantly higher than in men receiving warfarin $(64.3 \pm 23.3 \%$ vs $61.5 \pm 18.8 \%$, respectively; WaldWolfowitz; $p<0.05)$, whereas this difference wasn't found in women. Lower level of drug adherence was also demonstrated among men compared with

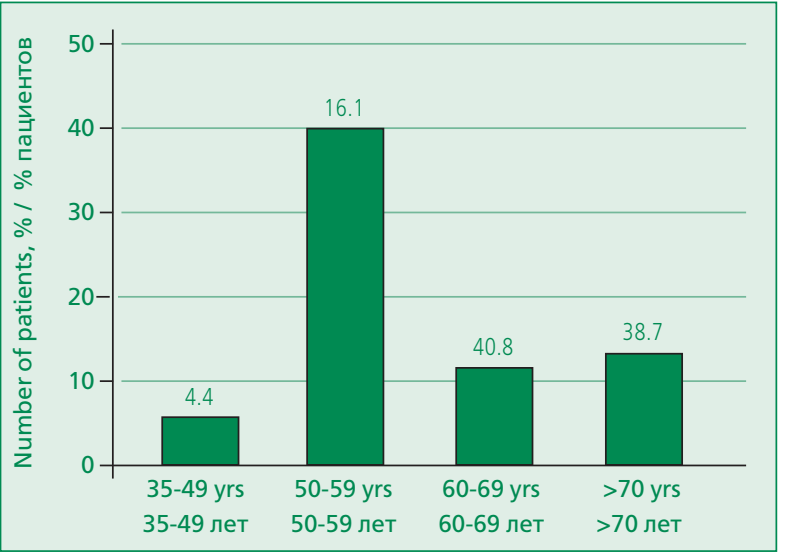

Figure 1. Age structure of study participants

Рисунок 1. Возрастная структура участников исследования купностям использовали критерии Wald-Wolfowitz, Mann-Withney, Kolmogorov-Smirnov, Kruskal-Wallis, Pierson и медианный критерий. Для проверки гипотез о принадлежности связанных выборок к однородным совокупностям применяли критерии Wilcoxon, Friedman и Kendall, а также ранговые коэффициенты корреляции Spearman $\left(\rho_{s}\right)$ и Kendall $(\tau)$. Независимость измеряемых переменных в номинальной шкале проверяли критериями Fisher и Pierson $\chi^{2}$. Отсутствие эффекта воздействия оценивали критериями McNemar и Cochran. Статистическая обработка материала выполнена при помощи статистического пакета Statistica 6.1 (Statsoft Inc., США).

\section{Результаты}

Из включенных в исследование пациентов $(n=137)$ было 68 мужчин (средний возраст 65 $\pm 10,3$ лет; индекс массы тела 31,3 $66,1 \mathrm{kг} / \mathrm{M}^{2}$ ) и 69 женщин (средний возраст

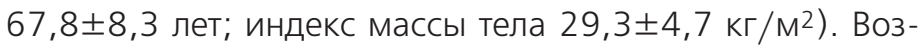
растная структура участников исследования представлена на рис. 1.

Среди пациентов впервые выявленная форма ФП наблюдалась в 4 случаях (2,9\%), пароксизмальная форма - в 44 (32,1\%), персистирующая форма - в 47 (34,3\%), постоянная форма - 42 случая (30,7\%). Антиагреганты получали 48 пациентов (35\%), антикоагулянты - 89 (65\%), из них 62 принимали варфарин (45,3\%), 27 - HOAK (19,7\%).

Пациенты, получавшие антикоагулянты, демонстрировали в целом более низкий уровень приверженности к лечению в сравнении с пациентами, не получавшими антикоагулянты. Наиболее значимыми являлись различия по уров-

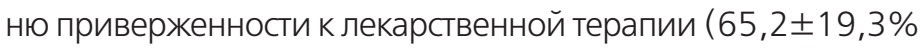
против 68,5 $\pm 19,1 \%$, соответственно; Wald-Wolfowitz; $p<0,05)$. Мужчины оказались существенно менее привержены к лечению, чем женщины: приверженность к ле-

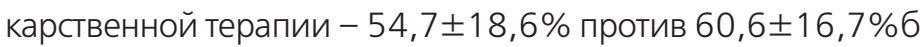
соответственно (Kolmogorov-Smirnov; $p<0,05$ ); приверженность к медицинскому сопровождению - 60,1 $19,6 \%$ против 70,2 $\pm 17,8 \%$, соответственно (Wald-Wolfowitz; $p<0,05)$.

Наконец, приверженность к лечению (без учета пола) была ниже у пациентов, принимавших варфарин, чем HOAK $(63,8 \pm 19,2 \%$ против 68,3 $\pm 19,7 \%)$, хотя статистической значимости эти различия не достигли. Среди мужчин, получавших НОАК, приверженность к медицинскому сопровождению была значимо выше, чем у получавших вар-

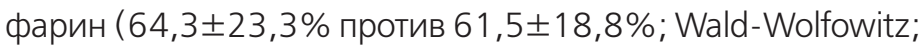
p $<0,05)$, у женщин же такие различия отсутствовали. Кроме того, принимавшие варфарин мужчины оказались менее привержены к лекарственной терапии, чем женщины

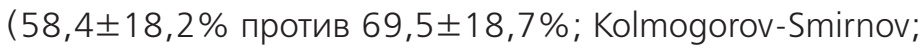
$\mathrm{p}<0,05)$.

При анализе частоты носительства полиморфных аллелей СYP2C9*2 и СYP2C9*3 гена СYP2C9 среди пациентов, включенных в исследование, установлено, что их распространенность имеет популяционные особенности. Встре- 
women receiving warfarin $(58,4 \pm 18,2 \%$ vs. 69,5 $\pm 18,7 \%$; Kolmogorov - Smirnov; $p<0.05)$.

When analyzing the prevalence of polymorphic CYP2C9*2 and CYP2C9*3 alleles of CYP2C9 gene among patients enrolled in the study, some special population characteristics were demonstrated. The incidence of polymorphic CYP2C9*2 allele was $20.7 \%$ while CYP2C9*3 allele was registered in $12.2 \%$ of patients. Overall rate of CYP2C9 gene mutation was $32.9 \%$. The allele CYP2C9*3 was significantly more frequent in men $(15.4 \%)$ than in women $(9.3 \%)$ (Pierson, $\chi^{2<0.05)}$. The difference in CYP2C9*2 prevalence between men $(17.9 \%)$ and women (23.3\%) was non-significant. The presence of CYP2C9*3 polymorphism leads to maximal reduction of CYP2C9 enzyme activity and, consequently, to greater risk of bleeding and drug interactions during warfarin treatment. Therefore the higher prevalence of CYP2C9*3 in men should be considered when choosing anticoagulant therapy.

Taking into account that some medications (amiodarone, losartan, torasemide etc.) may also influence on CYP2C9 enzyme activity, we evaluated the frequency of prescription of drugs that reduce the activity of CYP2C9. It was shown that 36 patients took amiodarone, among them $30.5 \%$ demonstrated mutations in CYP2C9 gene. Losartan was administered to $10 \mathrm{pa}$ tients with 1 case of CYP2C9*2 polymorphism. Torasemide was included in the treatment scheme of 42 patients, where $28.6 \%$ were carriers of CYP2C9 gene mutation. At the same time 17 patients took both amiodarone and torasemide while 4 of them shown CYP2C9 mutations.

During VKORC1 gene mutation analysis the prevalence of polymorphic alleles (isolated C+1173T and $\mathrm{G}+3673 \mathrm{~A}$ or their combination) was $68.3 \%$ (66.7\% in men and $69.7 \%$ in women). The mutant 1173 allele was observed in $62.1 \%$ patients $(64.1 \%$ in men and $60.5 \%$ in women). Overall rate of heterozygous form $(C / T)$ of 1173 allele was $54.8 \%$ (56.4\% in men and $53.5 \%$ in women). The mutant homozygous form $(T / T)$ of 1173 allele was found in $7.3 \%$ of patients ( $7.7 \%$ in men and $6.9 \%$ in women). It should be noted that patients with $1173(\mathrm{~T} / \mathrm{T})$ genotype had minimal synthesis rate and therefore minimal concentration of phylloquinone-epoxide reductase enzyme which determined tendency to excessive anticoagulation.

Polymorphism of 3673 allele was observed in $64.6 \%$ of patients $(64.1 \%$ in men and $65.1 \%$ in women). The rate of heterozygous form ( $G / A)$ of 3673 allele was found in $50 \%$ of patients $(48.7 \%$ in men and $51.2 \%$ in women) while $14.6 \%$ of patients (15.4\% in men and $13.9 \%$ in women) revealed homozygous form (A/A). These polymorphisms may in- чаемость полиморфного аллеля СYР2C9*2 составила 20,7\%, аллеля СYP2C9*3 - 12,2\%. Суммарно мутации гена СYP2С9 обнаружены у 32,9\%. Аллель СYР2С9*3 встречался значимо чаще у мужчин - 15,4\%, чем у женщин - 9,3\%

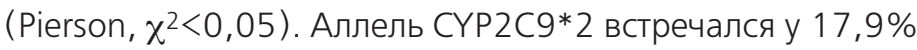
мужчин и у 23,3\% женщин, однако различия не имели статистической значимости. Наличие полиморфного аллеля CYP2C9*3 приводит к более выраженному снижению активности фермента СҮР2С9 и, следовательно, к большему риску кровотечений и лекарственных взаимодействий на фоне терапии варфарином. У мужчин риск наличия CYP2C9*3 оказался выше, чем у женщин, что необходимо учитывать при подборе антикоагулянтной терапии.

Учитывая, что на активность фермента СҮР2С9 влияет не только наличие мутаций, но и прием ряда лекарств (амиодарон, лозартан, торасемид), была изучена частота назначений препаратов, снижающих активность СYР2C9. Оказалось, что амиодарон принимали 36 человек, из них у 30,5 \% обнаружены мутации гена СYР2C9. Лозартан принимали 10 человек, из них у 1 обнаружен аллель СYР2C9*2. Торасемид входил в схему лечения у 42 человек, из них 28,6\% - носители мутаций гена СҮР2С9. При этом 17 человек принимали одновременно амиодарон и торасемид, из которых у 4 обнаружены мутации СYР2C9.

При анализе мутаций гена VKORC1 выявлено, что распространенность полиморфных аллелей (совместное или изолированное (+1173Т и G+3673A) составила 68,3\% (66,7\% у мужчин и 69,7\% у женщин). Мутантный аллель 1173 встречался у 62,1\% обследуемых (64,1\% мужчин и 60,5\% женщин). Аллель 1173 в гетерозиготной форме (C/T) был обнаружен у 56,4\% мужчин и 53,5\% женщин, а в целом - у 54,8\% обследуемых. Мутантная гомозиготная форма аллеля 1173 (Т/Т) встречалась у 7,3\% больных (7,7\% мужчин и 6,9\% женщин). Отметим, что у лиц с генотипом 1173 (Т/Т) скорость синтеза, а потому и концентрация фермента филлохинон-эпоксидредуктазы минимальна, что обуславливает выраженную склонность к антикоагуляции.

Полиморфизм аллеля 3673 обнаружен у 64,6\% пациентов (64,1\% мужчин и 65, 1 \% женщин). Аллель 3673 в гетерозиготной форме (G/A) обнаружен у 50\% обследуемых (48,7\% мужчин и у 51,2\% женщин), в гомозиготной форме $(\mathrm{A} / \mathrm{A})$ - у 14,6\% (15,4\% мужчин и 13,9\% женщин). Мутации указанных аллелей в разной степени повышают активность филлохинон-эпоксидредуктазы и могут стать причиной развития геморрагических осложнений на фоне терапии варфарином.

Обнаруженное у 7,3\% больных сочетание полиморфных гомозиготных форм аллелей C+1173T и G+3673A гена VCORC1 более чем на 40\% повышает концентрацию варфарина и создает дополнительные риски в отношении геморрагических осложнений антикоагулянтной терапии.

Одновременное носительство мутаций гена VCORC1 и СҮР2С9 составило 21,9\%, встречаясь у $25,6 \%$ мужчин и $18,6 \%$ женщин. 
crease phyllochinone-epoxide reductase activity in different degrees and may contribute to bleeding complications during warfarin therapy.

The combination of polymorphic forms of homozygous C+1173T and G+3673A alleles of VCORC1 gene diagnosed in $7.3 \%$ of patients. This combination is associated with more than $40 \%$ increase in warfarin plasma concentration and additional risks of hemorrhagic complications of anticoagulant therapy.

The rate of simultaneous carrier of VCORC1 and CYP2C9 gene mutations was $21.9 \%$ (25.6\% in men and $18.6 \%$ in women).

\section{Discussion}

The prevalence of CYP2C9 gene mutations varies between different ethnic groups. For example, the rate of CYP2C9*2 and CYP2C9*3 allele polymorphism in European population is estimated to be $15.7 \%$ and $15 \%$, respectively. However, allele CYP2C9*2 is not detected in Asian population while CYP2C9*3 variant is diagnosed in $1.5-3 \%$ of cases [5].

Studies of CYP2C9 mutation prevalence in Russia are lacking yet. The rate of CYP2C9*2 gene polymorphism in Stavropol region was about $25.4 \%$ of Slavs and $23.7 \%$ of Armenians. CYP2C9*3 allele was detected in $29 \%$ of Armenians and $12.7 \%$ of Slavs [6]. The estimated prevalence of CYP2C9*2 and CYP2C9*3 variants in the European part of Russia (St. Petersburg) was $11.11 \%$ and $6.32 \%$, respectively [7].

In our study, the regional occurrence of CYP2C9 gene polymorphism was significantly higher compared to Asian population (Pierson, $\chi^{2<0.05}$ ) but did not differ from the European population. Comparative analysis of Russian statistic data showed that the incidence of different alleles of CYP2C9 gene in the Omsk region was significantly higher compared to the European part of Russia (St. Petersburg) (Pierson, $\left.\chi^{2}<0.05\right)$. It was also demonstrated that the prevalence of CYP2C9*3 allele was lower than in Armenian population of Stavropol region (Pierson, $\chi^{2<0.05}$ ).

High incidence of VCORC1 gene mutations requires close monitoring of anticoagulation. Patients of this group usually need lower dose of warfarin and have to be under thorough INR control with recommendations of high adherence to diet and medication regimen. Changing the dose, cancellation or prescribing of concomitant drugs metabolized by CYP2C9 enzyme complex also requires tight INR control. This is really possible only in case of high medical adherence; otherwise warfarin therapy in patients with mutations in VCORC1 and CYP2C9 genes is associated with high risk of complications.

It is known that high adherence to treatment is one of the potential contributing factors to safety profile of anticoagulant therapy because even stable dose reg-

\section{Обсуждение}

Частота мутаций гена СYР2С9 в различных этнических группах неодинакова. Так, в европейских популяциях аллель CYP2C9*2 выявляется в 15,7\%, а аллель СYP2C9*3 - в 15\%. В азиатских популяциях аллель СРР2C9*2 не обнаружен, а СРР2С9*3 выявляется в 1,5-3\% случаев [5].

Исследования распространенности мутаций СYР2С9 в России пока немногочисленны. В Ставрополье носительство CYP2C9*2 у славян составило 25,4\%, а у армян - 23,7\%. Аллель СРР2C9*3 был выявлен у армян в 29\% и у славян - в 12,7\% случаев [6]. В европейской части страны (СанктПетербург) частота встречаемости аллеля СYР2 C9*2 составила 11,11\%, а СРР2С9*3 - 6,32\% [7].

В нашем исследовании частота встречаемости полиморфизма гена СYР2С9 в регионе оказалась значимо боль-

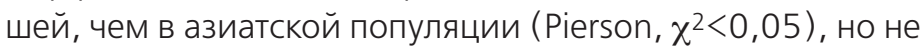
отличалась от европейской популяции. Сравнительный анализ российских статистических данных показал, что частота встречаемости полиморфизма гена CYP2C9 по исследуемым аллелям в Омской области значимо выше, чем у жителей европейской части России (Санкт-Петербург) (Pierson, $\left.\chi^{2}<0,05\right)$. Также выявлены отличия в распространенности аллеля СYP2C9*3 у представителей армянского этноса Ставропольского края, у которых встречаемость указанного аллеля оказалась выше (Pierson, $\chi^{2<0,05}$ ).

Высокая распространенность мутаций гена VCORC1 требует большой бдительности при контроле антикоагуляции. В этой группе пациентам требуется меньшая доза варфарина, тщательный контроль МНО, жесткое соблюдение диеты и режима приема лекарственных препаратов. Изменение дозы, отмена или назначение лекарств, метаболизирующихся с участием фермента CYP2C9, также требует дополнительного ужесточения контроля МНО. Эта рекомендация выполнима лишь у высоко приверженных к медицинскому сопровождению пациентов. При невозможности обеспечения качественного контроля у пациентов с мутациями генов VCORC1 и CYP2C9 терапия варфарином становится высоко рискованной.

Одним из основных факторов обеспечения безопасности терапии варфарином является высокая приверженность к лечению, поскольку даже при стабильной подобранной дозе концентрация варфарина в крови может увеличиться под действием лекарственных средств и продуктов питания, контроль за которыми на данный момент неосуществим. Для больных ФП, не демонстрирующих высокую приверженность к медицинскому сопровождению, в качестве антикоагулянта выбирать варфарин не следует. Одновременно наличие антикоагулянтов, в первую очередь варфарина, в схеме лечения сопровождается снижением приверженности к лекарственной терапии, в особенности у мужчин, тогда как использование НОАК (в большей степени у лиц мужского пола), ассоциировано с более высокой приверженностью к лекарственной терапии и медицинскому сопровождению. 
imen may be accompanied by increased concentration of warfarin due to uncontrolled intake of concomitant medications and food. Thus AF patients with low medical adherence shouldn't be administered warfarin as first line anticoagulant. And consequently longstanding anticoagulant therapy, particularly warfarin, is associated with reduced adherence to medical treatment, especially in men. However, patients on NOAC therapy are characterized by better compliance.

According to our data the high prevalence of hemostatic gene polymorphisms in Omsk region especially in men as well as their lower adherence to drug therapy and medical support may be associated with increased bleeding risk of warfarin therapy while NOAC administration may be required for this group of patients.

We believe that routine pharmacogenetics tests for VCORC1 and CYP2C9 gene mutations are not recommended to AF patients under the economic conditions. However, selected regional epidemiological studies of hemostatic gene polymorphisms may be effective to prevent complications of long-term anticoagulation and provide regional empirical algorithm of anticoagulants choice considering individual's treatment adherence. Patients from regions with high prevalence of VCORC1 and CYP2C9 gene mutations should be started with NOAC or lower doses of warfarin compared to anticoagulation therapy in general population. In case of low treatment adherence NOACs are recommended to be first choice medication to prevent thromboembolic complications.

\section{Conclusions}

High prevalence of CYP2C9 and VCORC gene polymorphisms in AF patients, especially in men, determines high risk of bleeding complications of warfarin therapy and provides the necessity of pharmacogenetic tests in this category of patients aimed to optimize choice of anticoagulation. In regions with high prevalence of hemostatic gene polymorphisms or when it is not possible to perform pharmacogenetic analysis the use of lower warfarin dose is recommended along with more frequent INR control or NOAC administration as first-line therapy. In patients with low adherence from regions with known high incidence of hemostatic gene mutations or when data are unavailable NOAC therapy should be performed.

Anticoagulation with NOACs should be also considered in AF patients when pharmacogenetic testing is failed or concomitant drugs metabolized by CYP2C9 enzyme system are required.

Disclosures. All authors have not disclosed potential conflicts of interest regarding the content of this paper.
Полученные в настоящем исследовании данные о высокой распространенности мутаций в Омском регионе, особенно среди мужчин, а также их более низкая приверженность к лекарственной терапии и медицинскому сопровождению убедительно свидетельствуют, что терапия варфарином несет в себе большие риски для этой категории пациентов. В таких случаях при необходимости назначения антикоагулянтов целесообразно останавливать выбор на HOAK.

По нашему мнению, в современных экономических, условиях сплошное рутинное выполнение фармакогенетического тестирования для определения мутаций генов VCORC1 и CYP2C9 у больных ФП нецелесообразно. Однако высокоэффективными для профилактики осложнений антикоагулянтной терапии могут оказаться выборочные региональные эпидемиологические исследования мутаций системы гемостаза, способные послужить основой для разработки региональных алгоритмов эмпирического выбора антикоагулянтов с учетом индивидуальной приверженности к лечению. В регионах с высокой распространенностью мутаций генов VCORC1 и CYP2C9 и при невозможности назначения НОАК целесообразно начинать стартовую терапию не с 5 мг варфарина, а с меньшей дозы. У пациентов с низкой приверженностью к лечению терапия варфарином проводиться не должна - в этом случае препаратами выбора для профилактики тромбоэмболических осложнений должны стать НОАК.

\section{Заключение}

Выявленная у больных ФП широкая распространенность полиморфизма генов CYP2C9 и VCORC1, в первую очередь - у мужчин, и определяемый этим высокий риск геморрагических осложнений обосновывает выполнение фармакогенетического теста в качестве метода выбора и модификации антикоагулянтной терапии. При невозможности выполнения фармакогенетического теста, а также в регионах с высокой распространенностью мутаций системы гемостаза для начала антикоагулянтной терапии целесообразно использовать уменьшенную стартовую дозу варфарина с увеличением кратности контроля МНО, либо использовать НОАК в качестве препаратов первого выбора. В регионах с известной высокой частотой встречаемости мутаций системы гемостаза и при условии низкой приверженности пациента к лечению, либо в случаях, если такие исследования не проводились, антикоагулянтную терапию следует выполнять НОАК.

При необходимости назначения больным ФП лекарственных средств, метаболизирующихся ферментом СYР2C9, и невозможности проведения фармакогенетического исследования антикоагулянтную терапию следует выполнять HOAK.

Конфликт интересов. Все авторы заявляют об отсутствии потенциального конфликта интересов, требующего раскрытия в данной статье. 


\section{References / Литература}

1. Wolf P, Abbott R, Kannel W. Atrial fibrillation as an independent risk factor for stroke: the Framingham Study. Stroke. 1991; 22(8): 983-8. doi: 10.1161/01.STR.22.8.983

2. Paul P, Dobesh, Fanikos J. Direct Oral Anticoagulants for the Prevention of Stroke in Patients with Nonvalvular Atrial Fibrillation: Understanding Differences and Similarities. Drugs. 2015; 75(14): 16271644. doi: 10.1007/s40265-015-0452-4

3. Poopak B, Rabieipoor S, Safari N, et al. Identification of CYP2C9 and VKORC1 polymorphisms in Iranian patients who are under warfarin therapy. Int J Hematol Oncol Stem Cell Res. 2015;9(4): 185-92.

4. Fung E, Patsopoulos NA, Belknap SM, et al. Effect of genetic variants, especially CYP2C9 and VKORC1, on the pharmacology of warfarin. Thromb Hemost. 2012; 38(8): 893-904. doi: 10.1055/s-00321328891.

5. Militaru FC, Vesa SC, Pop TR, et al. Pharmacogenetics aspects of oral anticoagulants therapy. J Med Life. $2015 ; 8(2): 171-5$

6. Carukjan AA. The prevalence of polymorphic variants of CYP2C9 * 2 and CYP2C9 * 3 gene cytochrome CYP2C9 residents of Stavropol Territory. Materials of the II inter-regional scientific-practical conference of young scientists and specialists "Medical science: a look into the future." Stavropol': StGMU; 2014. P. 108-13. (In Russian) [Царукян А. А. Распространенность полиморфных вариантов СYР2C9*2 и СҮР2C9*3 гена цитохрома СҮР2С9 у жителей Ставропольского края. Материалы II межрегиональной научно-практической конференции молодых ученых и специалистов «Медицинская наука: взгляд в будущее». Ставрополь: СТГМУ; 2014. С. 108-13]

\section{About the Authors:}

Yulia P. Skirdenko - MD, Teaching Assistant, Chair of Faculty Therapy and Occupational Diseases, Omsk State Medical University

Alexander V. Shustov - MD, cardiologist, Head of the Cardiology Department, Omsk Regional Clinical Cardiology Dispensary Valeriy V. Zherebilov - Teaching Assistant, Chair of Faculty Therapy and Occupational Diseases, Omsk State Medical University Nikolay A. Nikolayev - MD, Ph.D., Associate Professor,

Chair of Faculty Therapy and Occupational Diseases, Omsk State Medical University
7. Sirotkina OV, Ulitina AS, Taraskina AE, et al. Allelic variants CYP2C9 * 2 and CYP2C9 * 3 cytochrome CYP2C9 gene in the population of St. Petersburg and their clinical significance in anticoagulation therapy with warfarin. Rossijskij Kardiologicheskij Zhurnal 2004; (6): 47-50. (In Russian) [Сироткина O.B. Улитина А.С., Тараскина А.Е. и соавт. Аллельные варианты СүР2C9*2 и СүР2C9*3 гена цитохрома СҮР2С9 в популяции Санкт-петербурга и их клиническое значение при антикоагулянтной терапии варфарином. Российский Кардиологический Журнал 2004; (6): 47-50]

8. Nikolaev N.A. Prognosis of adherence to a constant drug therapy in participant of clinical trial. In: Nikolaev N.A., ed. Manual of clinical examination in internal medicine. Moscow: Izdatel'skij dom Akademi Estestvoznanija; 2015. (In Russian) [Николаев Н.А. Прогноз приверженности участника клинического исследования к постоянной лекарственной терапии. В: Николаев Н.А., ред. Руководство по клиническим исследованиям внутренних болезней. М.: Издательский дом Академии Естествознания; 2015].
Скирденко Юлия Петровна - ассистент кафедры факультетской терапии, профессиональных болезней ОмГМУ Шустов Александр Валентинович - врач-кардиолог, заведующий кардиологическим отделением № 3 ККД Жеребилов Валерий Валерьевич - ассистент кафедры факультетской терапии, профессиональных болезней ОмГМУ Николаев Николай Анатольевич - К.м.Н., доцент, доцент кафедры факультетской терапии, профессиональных болезней ОмГМУ 